NBER WORKING PAPER SERIES

\title{
INSTITUTIONS AND TECHNOLOGICAL INNOVATION DURING EARLY ECONOMIC GROWTH: EVIDENCE FROM THE GREAT INVENTORS OF THE UNITED STATES, 1790-1930
}

\author{
B. Zorina Khan \\ Kenneth L. Sokoloff \\ Working Paper 10966 \\ http://www.nber.org/papers/w10966 \\ NATIONAL BUREAU OF ECONOMIC RESEARCH \\ 1050 Massachusetts Avenue \\ Cambridge, MA 02138 \\ December 2004
}

We would like to express our appreciation to Marigee Bacolod, Yael Elad, Maria Loyola, John Majewski, Brian Rivera, Dhanoos Sutthiphisal, Steven Tse, Matthew Wiswall, Elaine Ycasas, and Tamara Zavalyenko for expert research assistance. We also gratefully acknowledge valuable discussions with Naomi Lamoreaux, Stanley Engerman, Larry Epstein, Phil Hoffman, Christine MacLeod, Gavin Wright, as well as participants at presentations at the NBER, Oxford University, the University of California, Los Angeles, the CESifo Conference on Institutions and Growth held in Venice, Italy in July 2004, and the 2004 annual meetings of the American Economic Association. The views expressed herein are those of the author(s) and do not necessarily reflect the views of the National Bureau of Economic Research.

(C) 2004 by B. Zorina Khan and Kenneth L. Sokoloff. All rights reserved. Short sections of text, not to exceed two paragraphs, may be quoted without explicit permission provided that full credit, including (C) notice, is given to the source. 
Institutions and Technological Innovation During the Early Economic Growth: Evidence from the Great Inventors of the United States, 1790-1930

B. Zorina Khan and Kenneth L. Sokoloff

NBER Working Paper No. 10966

December 2004

JEL No. N10, N71, O31, O34

\begin{abstract}
Employing a sample of renowned U.S. inventors that combines biographical detail with information on the patents they received over their careers, we highlight the impact of early U.S. patent institutions in providing broad access to economic opportunity and in encouraging trade in new technological knowledge. Through setting low fees and establishing administrative procedures for application, the United States deliberately created a patent system that allowed a much wider range, in socioeconomic class terms, of technologically creative individuals to obtain property rights to their inventions than did European patent institutions. Moreover, by requiring that applications be examined for novelty by technical experts, and by enforcing patent rights strictly, the U.S. system reduced uncertainty about the validity of patent rights, and in that way lowered the cost of transacting in them. Creating secure assets in new technological knowledge and facilitating access to markets in technology in this way both stimulated specialization at invention and further enhanced the opportunities available to technologically creative individuals who would otherwise have lacked the capital to directly extract returns from their efforts. Indeed, we show that until the late 19th century, the 'great inventors' of the U.S. generally had backgrounds that permitted them only limited formal schooling, and made extensive use of their abilities under the patent system to extract returns from trading their patent rights. The usefulness of the 19th century U.S. patent system to inventors with humble origins may have implications for the design of intellectual property institutions in contemporary developing countries.
\end{abstract}

\author{
B. Zorina Khan \\ Department of Economics \\ Bowdoin College \\ Brunswick, ME 04011 \\ and NBER \\ bkhan@bowdoin.edu
}

\author{
Kenneth L. Sokoloff \\ Department of Economics \\ UCLA \\ Los Angeles, CA 90095-1477 \\ and NBER \\ sokoloff@ucla.edu
}


Intellectual property institutions have long played a central role in discussions of economic growth. In recent years there has been a revival of concern with the impact of patent institutions on the rate and direction of inventive activity, and on technological change more generally. Much of the analysis has focused on the most direct effects of granting an exclusive property right in technological knowledge: the enhanced returns that inventors can extract by enjoying a state-mandated monopoly on their discoveries; and the higher costs that users of new technologies or consumers of final goods have to bear as a result of a society's recognizing property rights in technical information. For some decades, the dominant stream of thought held that the dynamic gains associated with more rapid rates of technological progress, induced by offering greater material incentives to investors in research and development, outweighed the static losses suffered because of slower diffusion. Scholars and policymakers have become increasingly skeptical about this calculus, however, with particular scrutiny of whether it is applicable to developing countries. Their chief concerns are that strengthened intellectual property rights in developing-country contexts might lead to a high volume of licensing or royalty fees from these societies to the highly industrialized countries, and that there might not be much of a return in terms of higher domestic rates of invention or productivity growth.

This paper draws on economic history to highlight another feature of intellectual property whose significance has received little attention. We argue that defining and enforcing a tradable asset in new technological knowledge is extremely important for fostering a market in technology, and for extending and increasing incentives for investment in inventive activity to segments of the population that would otherwise find it difficult to directly extract returns from their technological creativity. The paper explores this feature in the context of an assessment of the evolution of intellectual property systems, and its impact on the course of technological 
progress in one of the early industrializers, the United States. The historical perspective is valuable for appraising current issues, even though the effects and appropriateness of specific institutions such as patent system vary with the frontiers of technology as well as other circumstances which certainly change dramatically over time. In our view, the repercussions of providing broad access to property rights in new technological knowledge may be much more relevant and favorable for developing economies today than is generally realized.

In order to demonstrate just how revolutionary the United States patent system was in providing broad access to a secure and well-defined asset in new technological knowledge, the second section of this paper discusses the development of patent institutions in Britain and France, relative to America. Section III presents evidence regarding individuals who made contributions to the technological frontier in the nineteenth and early twentieth centuries. This part of the paper describes the composition of a sample of 'great inventors' and their patterns of patenting from 1790 through the 1930s. We examine patterns of geographical location, mobility, nativity, and access to privileges such as schooling at institutions of higher learning. Moreover, the data allow us to determine whether specific classes of 'great inventors' differed in their tendency to rely on the use of their patent as an asset that allowed them to extract returns from their technological creativity. We conclude with a brief discussion of how the U.S. innovation of a modern patent system diffused over the $19^{\text {th }}$ century, and the relevance to developing countries today of that country's experience with the role of institutions in fostering democratic invention.

\section{EARLY PATENT SYSTEMS}

A fundamental and enduring concern of organized society is the design of institutions that encourage private actors to undertake investments conducive to improvements in social welfare. It is therefore hardly surprising that there is a long history of public policies crafted to stimulate 
would-be inventors, innovators, and investors to contribute to the advance and diffusion of technological knowledge. Appreciation of the potential importance of such policies grew over the late-eighteenth and nineteenth centuries, as it became clear that ongoing technological progress was feasible, capable of altering the fate of nations, and responsive to material incentives. A wide variety of schemes were introduced and debated at one time or another, but by the end of the nineteenth century patent systems, and especially the model provided by the U.S., emerged as the dominant method by which national governments promoted the growth of new technological knowledge. An institution that had been rather obscure a century before had come to be regarded as a virtual necessity for any country with plans to industrialize or modernize. ${ }^{1}$

As emerging nations decided to establish or revise their patent institutions, they were able to draw from the examples and experiences of the three leading industrialized countries of the early nineteenth century, each of which was also something of a pioneer in formulating public policy toward technology. Britain - the first industrial nation - stands out for having established a patent system which has been in operation for a longer period than any other in the world. ${ }^{2}$ Patents were granted "by grace of the Crown" and were subject to any restrictions that the government cared to impose, including the expropriation of the patent without compensation. To a large degree by design, patent institutions offered rather limited incentives to inventors with only modest resources or to creators of incremental inventions. Specific features of the British system made it difficult for an inventor who did not already command capital to obtain and use a patent as a well-defined asset to mobilize that capital from others, or to extract a return to his

\footnotetext{
${ }^{1 .}$ Especially after the Crystal Palace Exhibition of 1851, there was a continued fascination with issues about patent systems, including whether patent systems were desirable for all countries, how they should be designed, and (for individuals) how to make money from them. See Machlup and Penrose (1950) for an excellent account of one part of the debate. Mark Twain was not far from the mainstream when he spoke through the "Connecticut Yankee in King Arthur's Court"(p. 70): "[T] he very first official thing I did, in my administration - and it was on the very first day of it too - was to start a patent office; for I knew that a country without a patent office and good patent laws was just a crab and couldn't travel any way but sideways or backways."
} 
technological creativity by selling it off. The orientation of the British system reflected a widespread view amongst that country's elite that significant (in the sense of technologically important, not being easily discoverable by many people, and thus worthy of property protection) contributions in technical knowledge were unlikely to come from individuals who did not already have access to the means to absorb the cost of a patent or to exploit the invention directly through a commercial enterprise.

The Statute of Monopolies in 1624 offered a grant of a patent for fourteen years for "the sole making or working of any manner of new manufacture within this realm to the first and true inventor." 3 But in Britain the interpretation of the "first and true inventor" included importers of inventions that had been created abroad, and seems to have also intruded on the determination of whether employers were entitled to patents on the ideas of their workers. ${ }^{4}$ Not only were fees set extremely high (five to ten times annual per capita income well into the $19^{\text {th }}$ century), but potential patentees were well advised to obtain the help of a patent agent to aid in negotiating the numerous steps and offices that were required for a cumbersome process of application in London. Before 1852 patent specifications were open to public inspection on payment of a fee, but they were not printed, published or indexed. ${ }^{5}$ The complicated system also inhibited the diffusion of information and made it difficult, if not prohibitive, for inventors outside of London to conduct patent searches.

The defects of the British system led to numerous investigations and calls for institutional reform, especially after 1829. But it was not until the Crystal Palace Exhibition in 1851, where

\footnotetext{
2 The standard references for the early British patent system are Christine Macleod (1988) and H I Dutton (1984).

321 Jac. I. C. 3, 1623, Sec. 6.

${ }^{4}$ See Macleod (1999) for a discussion of how craftsmen in Britain had to rely on other methods of extracting returns from their ideas about how to improve on technical practice.

${ }^{5}$ Since the patent could be filed in any of three offices in Chancery, searches of the prior art involved much time and inconvenience. It is hardly surprising that the defenders of the early patent system included patent agents and patent lawyers. Patent fees also provided an important source of revenues for the Crown and its employees, and
} 
American inventors shocked observers with their creativity and called attention to their innovative patent institution, that actual legislation was enacted to meet some of the longstanding criticisms. In 1852 the British patent laws were revised in the first major adjustment of the system in two centuries. The patent application process was rationalized into one single Patent Office, and the fee structure was adjusted. A renewal system was adopted, making it cheaper to initially obtain a patent, but one taken to full term remained just as costly as before. The 1852 reforms undoubtedly instituted improvements over the former opaque procedures, but the system remained one based on registration rather than examination, and procedures continued to discourage the technologically creative who did not already have substantial capital to draw on.

This absence of an examination system was, we argue, extremely important. Without examination, there was great uncertainty about what a patent was really worth. Before the 1852 reform, for example, the lack of access to information about the specifications of patents already granted made it difficult to identify whether a purported invention (even one that had been patented) was truly novel and would stand up to challenge. The legal system added to the prevailing uncertainty, and was biased against "mere" improvements. Patents were valid only for inventions that were novel (which was of course difficult to determine before 1852) and useful, and courts did not hesitate to enforce both of these conditions. Utility under the patent law was regarded as unrelated to the commercial success of the patented invention. Since the legal system was unpredictable, patent rights could not be regarded as settled unless the patent had been contested in court with a favorable outcome. ${ }^{6}$ Moreover, as the law did not offer any relief to the purchaser of a patent that ultimately proved invalid or worthless, potential purchasers were

created a class who had strong incentives to block proposed reforms.

6 According to an editorial in 1862, "there can be no doubt that a large amount of property is bound up in patent rights, and that the utmost uncertainty exists as to the legal value of that property" (Newton's London Journal, cited in Coulter, p. 140). Other constraints on the market for inventions related to policies towards assignments. Ever vigilant to protect an unsuspecting public from fraudulent financial schemes on the scale of the South Sea Bubble, 
well advised to engage in extensive searches before entering into contracts. ${ }^{7}$ When coupled with the lack of assurance inherent in a registration system, the purchase of a patent right involved a substantive amount of risk and high transactions costs -- all indicative of a speculative instrument. It is therefore not surprising that the prevalence of assignments and licenses was significantly lower than in the U.S. (see Figure 1$){ }^{8}$

France provides another example of European institutions to promote invention and technical change. French policies consisted of an extensive array of rewards and incentives, and illustrate the relative benefits and costs of alternative routes to statutory grants of patent rights. ${ }^{9}$ Although offering some striking contrasts with the approach taken by Britain, overall they were alike in offering quite limited incentives for technologically creative individuals without either comfortable means or high status to invest in developing their ideas. The cost of obtaining patents was again very high relative to per capita income (much higher than in the U.S., though lower than in Britain). Similarly, the reliance on a registration system, limited public disclosure of technical specifications, and the absence of a centralized way of tracking of assignments and patent ownership, all made it difficult for patentees to use their patents as secure and well-defined assets to mobilize capital or to extract significant returns through selling or licensing off his/her rights. France was distinguished by its readiness to make extensive use of other means of rewarding inventors and innovators, but those sorts of returns were uncertain, especially since the processes involved in identifying those deserving of support tended to favor individuals who

ownership of patent rights was limited to five investors (later extended to twelve).

${ }^{7}$ The case law on licenses was more convoluted. See for instance Lawes v. Purser, 6 Ell. and B1. 930, where a licensee refused to continue payments on the grounds that the patent was void. It was held that the licensee could not make such a defense as long as the contract for the invalid patent had been executed without fraud.

${ }^{8}$ The markedly higher ratio of assignments to patents in the U.S. is all the more significant, both because the British figures are biased upward by the inclusion of licenses, and because the higher costs of obtaining a patent in Britain should, at least in principle (if screening by cost was a good substitute for screening by examination), have led to patents of higher average quality.

${ }^{9}$ Excellent assessments of such issues during the Enlightenment include Liliane Hilaire-Perez's thesis, "Inventions 
already established economically, professionally, or socially.

Before the Revolution, the advance of technology was encouraged by the state granting inventors or introducers of inventions titles, pensions that sometimes extended to spouses and offspring, loans (some interest-free), lump-sum grants, bounties or subsidies for production, exemptions from taxes, or monopoly grants in the form of exclusive privileges. Alternatives to formal privileges illustrate the advantages and disadvantages of awards that were administered by the state on a case- by- case basis. These primarily nonmarket methods of allocation tended to be administratively costly and were imbued with the potential for corruption. It is, and was, evident that a system of grants and privileges could be arbitrary and based on non-economic criteria. Eighteenth-century correspondence and records provide numerous examples of awards that were made based on court connections. Members of the scientific community who examined applications were not necessarily qualified to assess the potential value of many of the inventions. Moreover, the administrative and opportunity costs of such a system were nontrivial on the part of both supplicants and the state bureaucracy. Inventors were also aware that promises extended to them as inducements were not necessarily enforceable once the inventor had made fixed investments or made his discovery. ${ }^{10}$ The technologically creative who were lacking in wealth, status, or connections to individuals who enjoyed these privileges, were at a pronounced disadvantage.

It was this complex network of state policies towards inventors and their inventions that

et Inventeurs en France et en Angleterre au XVIIIe siecle," and L'invention technique au siecle des Lumieres, Paris : Albin Michel, 2000.

${ }^{10}$ The famous English textile inventor, John Kay, illustrates the asymmetries involved in individual bargains struck with state authorities. Kay settled in France because of promises to subsidize the transfer of technology and substantially aided in the diffusion of textile machinery. The Society for the Encouragement of Arts and Manufacturing in England promised him a generous award to return there, but then reneged once he was in London. Kay wrote early in 1761 to Prudaine de Montigny, Conseiller d'Etat in London, to explore the possibility of receiving French financial aid if he again immigrated to Paris. Later that same year, Kay wrote to M. de Brou, Intendant de Rouen, to complain that he was still not receiving the pension he had been promised. 
was replaced after the outbreak of the French Revolution. The modern French patent system was established according to the laws of 1791 (amended in 1800) and 1844. The Revolutionary

Assembly intended to avoid the excesses involved in previous grants of privileges, and

proclaimed that it had drafted the outlines of a system that constituted a distinct break with the

past. But in effect, as Alexis de Tocqueville pointed out, many features of the institutions of the

ancien regime survived the revolution, and this was no less evident in the workings of the patent

system. ${ }^{11}$ The 1791 statute stipulated patent fees that were costly, ranging from 300 livres

through 1500 livres, and the high price of protection led to difficulties for inventors from

ordinary backgrounds. Patentees filed through a simple registration system without any need to specify what was new about their claim, and could persist in obtaining the grant even if warned that the patent was likely to be invalid. Indeed, on each patent document the following caveat was printed: "The government, in granting a patent without prior examination, does not in any manner guarantee either the priority, merit or success of an invention." 12

The French patent statutes included a statement regarding the right of the public to view patent specifications, which echoed the "bargain" theory of patents that underlay American and

\footnotetext{
${ }^{11}$ See the Decret du 30 Decembre 1790, in the Code des Pensions, p. 45. Although the legal rhetoric implied that the primary intent of the legislation was to recognize the natural rights of inventors, the actual clauses led to results that were different and reflected former mercantilist policies. In an obvious attempt to limit international diffusion of French discoveries, until 1844 patents were voided if the inventor attempted to obtain a patent overseas on the same invention. On the other hand, the first introducer of an invention covered by a foreign patent would enjoy the same "natural rights" as the patentee of an original invention or improvement, although the term would expire at the same time as any foreign patent on the item. In order to qualify for a patent of importation, the applicant had to have obtained practical knowledge of how the item worked through personal risk and effort, although he was not obliged to prove that the invention had been patented elsewhere nor to even state its country of origin. The rights of patentees were also restricted if the invention related to items that were controlled by the French government, such as printing presses and firearms.

${ }^{12}$ Since France during the ancien regime was likely the first country to introduce systematic examinations of applications for privileges, it is somewhat ironic that commentators point to the retention of registration without prior examination as the defining feature of the "French system." In 1968 a partial examination system was adopted which was similar to the early British reforms along these lines, since it did not include a search for novelty, merely a test for accordance with the law: "[il] se situe a mi-chemin entre la libre deliverance et l'examen prealable ... en effet, l'administration n'avait pas les moyens de pratiquer un tel examen." (P. 21, La Procedure Francaise de Delivrance des Brevets d'Invention, Yves Marcellin, Editions Cedat, Rosny-Sous-Bois.) The changes were made to give value to patents and to protect the interests of third parties. It was only in 1978 that an examination for novelty
} 
British grants. In return for the limited monopoly right, the patentee was expected to describe the invention in such terms that a workman skilled in the arts could replicate the invention and this information was expected to be "rendue publique". However, since no provision was made for the publication or diffusion of these descriptions, in effect the statutory clause was a dead letter. At least until the law of April 7 1902, specifications were only available in manuscript form in the office in which they had originally been lodged, and printed information was limited to brief titles in patent indexes. ${ }^{13}$ Moreover, the state remained involved in the discretionary promotion of invention and innovation through policies beyond the granting of patents such as cash awards and purchase of patent rights. As a result, inventors had an incentive to direct their attention to rent seeking activities as well as to productive efforts to commercialize their discoveries. Patent assignments were filed in the office of the Prefect for the district, but since there was no central source of information it was difficult to trace the records for specific inventions. Like patents themselves, assignments and licenses were issued with a caveat emptor clause. This was partially due to the nature of patent property under a registration system, and partially to the uncertainties of legal jurisprudence in this area. In short, according to an informed $19^{\text {th }}$ century observer, patent rights evinced a "remarkably hazardous and uncertain nature." The basic structure and principles of the French patent system set forth in these early French statutes endured until after World War II.

The framers of the U.S. Constitution and its early laws were bold, ambitious, and optimistic, and helped set the new nation on an institutional trajectory that was radically different from any in the Old World. One of the areas in which they made this dramatic break was in the

\footnotetext{
was introduced.

${ }^{13}$ The law of 1844 only allowed for the publication of the full text of patents that were judged to be important. The attempt to obtain information was also inhibited by restrictions placed on access - viewers had to state their motives; foreigners had to be assisted by French attorneys; and no extract from the manuscript could be copied until the patent had expired. 'C'est donc bien avec la loi de 1902 que le brevet a definitivement perdu son charactere de
} 
patent system they constructed. The so-called Founding Fathers took the design of intellectual property institutions very seriously: for the first time in the world an intellectual property clause was introduced in a national constitution; the intellectual property clause was approved unanimously and the law establishing the patent system was one of the first passed by Congress; and prominent figures such as James Madison and George Washington played key roles in spelling out the provisions. The framers quite self-consciously made major changes to the structures employed in Europe, and nearly all of their alterations can be viewed as strengthening and extending incentives and opportunities for inventive activity to classes of the population that would not have enjoyed them under traditional intellectual property institutions.

The framers of the U.S. Constitution and of its early laws were familiar with European precedents, and so it might be reasonably inferred that their innovations in design were selfconscious and deliberate. The intellectual property clause providing for the patent and copyright statutes appears in the very first Article of the U.S. Constitution, whereby Congress was instructed to "promote the Progress of Science and useful Arts, by securing for limited Times to Authors and Inventors the exclusive Right to their respective Writings and Discoveries." From what record of their thinking survives, the framers were intent on crafting a new type of system that would promote learning, technology, and commercial development, as well as create a repository of information on prior art. Their chosen approach to accomplishing these objectives was based on providing broad access to property rights in technology, which was achieved through low fees and an application process that was impersonal and relied on routine administrative procedures. Congress debated the question of appropriate fees, and the first patent law in 1790 set the rate at the minimal sum of $\$ 3.70$ plus copy costs. In 1793 the fees were increased to $\$ 30$ (less than 5 percent of those prevailing in Britain), and were maintained at this

document d'archives.” Brevets d'Invention Francais, 1791-1902, p. 12. 
level until 1861. In that year, they were raised to $\$ 35$, and the term was changed from fourteen years (with the possibility of an extension) to seventeen years (with no extensions.)

Incentives for generating new technological knowledge were also fine-tuned by requiring that the patentee be "the first and true inventor" anywhere in the world. The law employed the language of the British statute in granting patents to "the first and true inventor," but unlike in Britain, the phrase was used literally, to grant patents for inventions that were original in the world, not simply within U.S. borders. Moreover, a condition of the patent award was that the specifications of the invention be available to the public immediately on the issuance of the patent. ${ }^{14}$ This latter condition not only sped the diffusion of technological knowledge, but also -when coupled with strict enforcement of patent rights -- aided in the commercialization of the technology. That strict enforcement was indeed soon forthcoming. Within a few decades the federal judiciary evolved rules and procedures to enforce the rights of patentees and their assignees, and clearly considered the protection of the property right in new technological knowledge to be of vital importance. ${ }^{15}$ Unlike in Britain, patent property was secured by the "Supreme Law of the land" (the Constitution) and, once granted, could not be overturned except for cases of outright fraud.

Another distinctive feature of the U.S. system of great significance was the requirement that all applications be subject to an examination for novelty. For the first few years after the

\footnotetext{
${ }^{14}$ American legislators were concerned with ensuring that information about the stock of patented knowledge was readily available and diffused rapidly. As early as 1805 Congress stipulated that the Secretary of State should publish an annual list of patents granted the preceding year, and after 1832 also required the publication in newspapers of notices regarding expired patents. The Patent Office in Washington itself was a source of centralized information on the state of the arts, but it also maintained repositories throughout the country, where inventors could forward their patent models at the expense of the Patent Office. Rural inventors could apply for patents without significant obstacles, because applications could be submitted by mail free of postage.

${ }^{15}$ See Khan 1995. Supreme Court Justice Joseph Story, the acknowledged intellectual property expert of the early courts, succinctly stated the dominant perspective in Lowell v. Lewis [15 F. Cas. 1018 (1817)]: "[T]he inventor has a property in his invention; a property which is often of very great value, and of which the law intended to give him the absolute enjoyment and possession ... involving some of the dearest and most valuable rights which society acknowledges, and the constitution itself means to favor."
} 
Patent Act of 1790 was passed, a committee comprising the Secretaries of State and War, and the Attorney General examined the patent applications. This provision proved unwieldy and was replaced by a registration system in 1793 , whereby disputes about the validity of a patent were to be resolved by the judiciary. The Patent Act of 1836 re-introduced the examination system, in a structure that remains in use today. Each application was to be scrutinized by technically trained examiners to ensure that the invention conforms to the law and constitutes an original advance in technology. ${ }^{16}$ Approval from technical experts reduced uncertainty about the validity of the patent, and meant that the inventor could more easily use the grant to either mobilize capital to commercially develop the patented technology, or to sell or license off the rights to an individual or firm better positioned to directly exploit it. Private parties could always, as they did under the registration systems prevailing in Europe, expend the resources needed to make the same determination as the examiners, but there was a distributional impact, as well as scale economies and positive externalities, associated with the government's absorbing the cost of certifying a patent grant as legitimate and making the information public. ${ }^{17}$ Trade in patented technologies was, as a result, much more extensive - even on a per patent basis - in the U.S. than elsewhere. Technologically creative people without the capital to go into business and directly exploit the fruits of their ingenuity were major beneficiaries.

It was not coincidental that the U.S. system was extraordinarily favorable to trade in patent rights. From the special provision made in the 1793 law for keeping a public registry of

\footnotetext{
${ }^{16}$ Although the statutes proposed to grant patents for "new and useful" inventions, in practice the utility claim was never enforced. Courts declared that it was up to the market, not to administrators, to determine what was useful. In the 1817 case, Lowell v. Lewis, 15 F. Cas. 1018, Joseph Story charged the jury that the utility of the invention "is a circumstance very material to the interest of the patentee, but of no importance to the public. If it is not extensively useful, it will silently sink into contempt and disregard." It was the role of the market, rather than the courts, to determine the ultimate success of the patent. This policy was continued by the Patent Office, which also did not attempt to gauge the social or technical value of an invention, deciding conflicting claims predominantly on the basis of novelty.

${ }^{17}$ See Dutton 1984 and MacLeod 1988 and 1999.
} 
all assignments onward, it is clear that the framers of the system expected and desired an extensive market in patents to develop. It was well understood that the patent system enhanced potential private and social returns to invention all the more, by defining and extending broad access to tradable assets in technological knowledge to a wide spectrum of the population. A market orientation enabled patentees to extract income (or raise capital) from their ideas by selling them off to a party better positioned for commercial exploitation, and thereby encouraging a division of labor that helped creative individuals specialize in their comparative advantage. The U.S. system extended the protection of property rights to a much broader range of inventions than obtained in Britain or elsewhere in Europe (largely through the lower costs) and, when coupled with effective enforcement of the rights of the "first and true inventor," this meant that inventors could advantageously reveal information about their ideas to prospective buyers even before they received a patent grant. By the mid-1840s, trade in patents (and patenting) was booming, and growing legions of patent agents or lawyers had set up shop in major cities and other localities where rates of patenting were high. Although these agents focused initially on helping inventors obtain patents under the new system, it was not long before they assumed a major role in the marketing of inventions. ${ }^{18}$

Overall, there is no serious question that the United States patent system constituted a dramatic break from European antecedents as regards policies to promote technological advance.

\footnotetext{
${ }^{18}$ By the mid-1840s, for example, a number of national patent agencies had begun to publish periodicals (such as Scientific American) that popularized invention as a career path for the ambitious and talented. Over time, intermediation in this market for technology grew ever more articulated in a process not unlike the evolution of financial intermediaries. Patent agents and lawyers became increasingly specialized and were drawn into activities such as the provision of advice to inventors about the prospects for various lines of inventive activity, and the matching not only of buyers with sellers of patents but also of inventors with individuals seeking to invest in the development of new technologies. As the extent of the market for technology expanded over the course of the nineteenth century, creative individuals with a comparative advantage in technology appear to have increasingly specialized in inventive activity. This tendency was likely reinforced by the increasing importance to inventors of specialized technical knowledge as technology became more complex. For evidence and more discussion, see: Lamoreaux and Sokoloff 1996, 1999, 2001, and 2003; Khan and Sokoloff 1993 and 2001; and Khan 2004.
} 
The framers of the U.S. patent institutions held quite different expectations, relative to those of their counterparts in Europe, about the extent to which individuals from relatively ordinary or humble backgrounds could contribute to new technological knowledge, and about how responsive that group would be to expanded opportunities for realizing returns from inventive activity. The structure of the U.S. system was based on the conception that a wide range of individuals, whatever their social origins and standing, were capable of making significant contributions to the advance of technological knowledge, but that in order to realize that potential, broad access to property rights in their knowledge had to be provided. Such rights were especially critical for the technologically creative of limited means. Without clear and secure property rights to their inventions, how could they hope to mobilize the capital to exploit them directly? Certainly, without such property rights (dependent both on their ability to obtain a patent, and on a high likelihood - enhanced by the examination system -- that it would stand up in court to a legal challenge), problems of asymmetric information and other high transactions costs would plague the attempts of inventors to attract investors, just as they would complicate the working out of arrangements between employers and employees to encourage the latter to develop their ideas for improvement and offer them up. Access to such rights was to be enhanced by lower fees, an examination system that bolstered confidence that a patent would stand up to challenge, and by a judicial system that was effective at enforcement. Requirements of immediate full disclosure of technical specifications stimulated further progress, as the technologically creative could more easily learn about and build on what had been discovered. Such measures also encouraged a market in patented technologies that would both aid inventors in using their patents as collateral to attract investments and increase the returns to their inventions.

One would expect this system to have led to a more socially diverse composition of 
inventors and, in previous work, based on general samples of patentees, we showed how individuals from elite backgrounds accounted for a much smaller proportion of patentees in the U.S. than they did in Britain during the early $19^{\text {th }}$ century. ${ }^{19}$ Because many patents are of little or no value, however, this evidence may not conclusively demonstrate that providing broader and stronger incentives for inventive activity was of much technological significance. ${ }^{20}$ Indeed, many observers, including those who were influential in maintaining the more socially restrictive patent systems that predominated in Europe until late in the $19^{\text {th }}$ century, thought that little in the way of new technology that was novel or important could be expected from individuals who lacked sufficient capital to obtain patents and fund their commercial application:

even with the present expense there are so many trifling patents taken out. If the fee was much higher, parties that are now taking out patents for little speculative things ...would not take them out. They are something like the dog in the manger; they prevent the public from benefiting by the invention or improvements on it for fourteen years, and yet do not benefit themselves. ${ }^{21}$

The next section of the paper therefore examines the backgrounds and careers of individuals who made contributions at the frontiers of technology, in order to determine the role of the patent system in providing broad access to opportunities for deriving income from investments in inventive activity. The focus on inventors who achieved renown for their contributions to the advance of technology seems fully appropriate for assessing whether the democratic orientation of the U.S. system supported important advances in technology.

\footnotetext{
${ }^{19}$ Khan and Sokoloff 1998.

${ }^{20}$ Sokoloff 1988; Sokoloff and Khan 1990; and Khan and Sokoloff 1993.

${ }^{21}$ So testified Charles Few to the Select Committee on the Law Relative to Patents for Invention, on May $15,1829$. See British Parliamentary Papers 1968, Reports from Select Committees on the Law Relative to Patents for Inventions, vol. 1, p.48.
} 


\section{EVIDENCE FROM THE ‘GREAT INVENTORS’ IN THE UNITED STATES}

The idea that patent institutions might matter for the rate of invention, by either a group or the entire population, is based on the judgment that inventors (and those who invest resources to support their activity) are motivated in part by the prospects of realizing material returns. As we have shown in previous work, early $19^{\text {th }}$ century U.S. inventors were indeed highly entrepreneurial and quite sensitive to the potential gains that could be extracted from their discoveries. Some scholars might agree with this characterization, but still contend that the roster of patents was limited to trivial improvements that were only of marginal relevance to the sources of productivity growth and technological change. A common argument is that economic growth depended on discrete advances vested in such "great inventions" as the telegraph, the railroad and the steam engine, and that such ideas were generated through a different process. We drew on the Dictionary of National Biography to locate those "great inventors" who were active in the U.S. at some point during their careers and born before 1886, and traced their patenting through 1930 , in order to examine how different their patterns of behavior were from those of patentees in general. For each of the more than 400 inventors (all men except for one woman), we collected biographical information as well as the records of a substantial proportion of the patents (roughly 4500 out of 16,900$)$ they were awarded over their careers

Overall, we find that the so-called great inventors were quite similar to ordinary patentees. Indeed, to the extent they differed, it was because they were even more entrepreneurial or influenced by markets. Not only did their patenting activity vary procyclically, as did patenting overall, but they often shifted the direction of their inventive activity (as reflected in patents) when exogenous events such as the Civil War altered the relative returns 
that could be expected from different sorts of inventions. ${ }^{22}$ It is also telling that more than 95 percent of the great inventors patented at least some of their inventions, and an even higher percentage took positive action to derive material benefit from them. ${ }^{23}$

Table 1 provides another powerful indication that inventors, and great inventors especially, were concerned with material returns. This is reflected in the tendency for inventors to disproportionately cluster in geographic areas (such as New England and the Middle Atlantic) with better or easier access to low-cost transportation (such as navigable internal waterways) and to the institutional supports underlying the market for technology (such as patent agents and lawyers). ${ }^{24}$ This geographic pattern is not explained by geographic differences in schooling levels or in the distribution of manufacturing workers. Rather it seems consistent with the notion that inventors were more likely to focus on inventive activity if they were in (due either to birth or selective migration) locations where returns to inventive activity were higher. ${ }^{25}$ Geographic differentials in patenting seem to have initially (during the early $19^{\text {th }}$ century) been rooted in transportation-based disparities in access to broad markets, but persisted over time especially since institutional supports to carrying out and profiting from invention tended to cluster where patenting was higher. The self-reinforcing pattern was completed when technologically creative individuals chose to move to those places where the market for technology was concentrated, in order to better realize the returns to their specializing at their comparative advantage in inventive

\footnotetext{
22 Sokoloff 1988; and Khan and Sokoloff 1993.

${ }^{23}$ This claim is based on a presumption that the 'great inventors' who were employees (a distinct minority as will be made clear), did take positive action to derive benefit. From the biographies we have read, there were only a few inventors who did not try to realize some returns from their efforts. Nearly all patented their inventions, but some did not. Only three of the cohort born after 1820 did not obtain patent protection.

${ }^{24}$ In previous work, we showed that both overall inventors, and especially great inventors, were highly disproportionately concentrated in counties with access to water transportation (prior to railroads). See Sokoloff 1988 and Khan and Sokoloff 1993. For evidence that patent agents and other indicators of the market for technology came to be disproportionately concentrated in those areas (mostly in New England and the Middle Atlantic), see Lamoreaux and Sokoloff 1996, 1999a, 1999b, and 2003.
} 
activity. $^{26}$ A final illustration of how entrepreneurial the great inventors were is the high rate of migration evident in all of the birth cohorts (see Table 2). The rates of inter-state migration we estimate from their places of birth and their residences during the years they received patents are much higher than those for the general population at similar ages. ${ }^{27}$

One of the key issues for our study is whether the framers of the U.S patent institutions were correct in their assumption that individuals from modest or undistinguished backgrounds were capable of playing important roles in pushing out the technological frontier. Although the biographies contain some information about the parents of the great inventors (see Table 2 for the occupations of their fathers), the relative paucity of data on the wealth holdings of the parents limits its usefulness for our purposes here. Instead, we take advantage of the abundant detail on the formal schooling and training the great inventors received early in their work or career histories. Historians of education agree, and the biographies confirm, that the age at which a young male left school and began to work was strongly associated with the economic resources of the parents during the $19^{\text {th }}$ century. ${ }^{28}$ This pattern stemmed both from most of the nation's secondary schools and universities being private and thus requiring significant tuition until late in the 1800s, as well as the opportunity cost of an individual at school in lieu of at work. The evidence on the extent of formal schooling among the great inventors, therefore, bears not only the significance of having received a higher level (and course of study) of formal schooling for

\footnotetext{
${ }^{25}$ See Khan and Sokoloff 1993 , for evidence that great inventors during the early $19^{\text {th }}$ century were both more likely to be born in counties with low-cost access to broad markets, and to migrate to such counties. Both factors contributed to the highly disproportionate concentration of great inventors in such counties.

${ }^{26}$ See Lamoreaux and Sokoloff 1996 and 1999 for more discussion.

${ }^{27}$ Joseph Ferrie very kindly provided estimates of the inter-state migration rates from the random sample of the native-born population that he has collected from the late- $19^{\text {th }}$ century public-use census records, for groups at comparable ages. He agrees that the great inventors seem to have been much more geographically mobile than the general population. It is also worth noting how the foreign born are disproportionately represented among the great inventors of the United States. This is consistent with the idea that the technologically creative in Europe were more likely to migrate across the Atlantic because of greater opportunities - some of which may have associated with the patent system.
} 
being capable of making important contributions to technology, but also on what sort of material circumstances they came from.

Figure 2 displays the distributions of patents across classes of great inventors distinguished in terms of the amount and type of formal schooling they received, and arrayed by birth cohort. It reveals that from the very earliest group (those born between 1739 and 1794) through the birth cohort of 1820 to 1845 , roughly 75 to 80 percent of patents went to those with only primary or secondary schooling. ${ }^{29}$ So modest were the educational backgrounds of these first generations of great American inventors, that 70 percent of those born during 1739-94 had at best a primary education (at least as formally provided), with the proportion dropping to only just above 59 percent among those who entered the world between 1795 and 1819 . Given that these birth cohorts were active and indeed dominant until the very last decades of the $19^{\text {th }}$ century, these figures unambiguously indicate that people of rather humble backgrounds were capable of making important contributions to technological knowledge. Those who had received some schooling at institutions of higher learning are admittedly over-represented, as the proportions of cohorts graduating from secondary school or college were lower than 10 percent and 3 percent respectively as late as $1900 .^{30}$ But what is most striking is how individuals who had not enjoyed the advantages associated with a more advanced education accounted for such a large share of major inventions, and that those trained in engineering and/or the natural sciences (in college or

\footnotetext{
${ }^{28}$ See Cubberley 1920, for a discussion of how the schools, and the backgrounds of the students who attended them, evolved over the $19^{\text {th }}$ century.

${ }^{29}$ Those classified as receiving only a primary education encompass a range from those who spent no time in school to those who attended school until about age 12. Those who were identified as spending any years in an academy or who attended school after the age of 12 (but did not attend a college or seminary) were placed in the secondary schooled category. Those who spent any time at all in college were either counted in the college category, or - if they had attended a school with an engineering orientation or followed a course of study in medicine or a natural science - in the engineering/natural science.

${ }^{30}$ See Snyder 1993, figures 11 and 17. The rates of graduation from secondary school and college were markedly higher in the Northeast and East North Central regions, where inventive activity was disproportionately concentrated throughout the $19^{\text {th }}$ century however. See Cubberley 1920 and 1947 for discussion of the regional patterns in schooling.
} 
beyond) did not play a major role until the birth cohort of 1846 to 1865 . Moreover, in all of the birth cohorts, the great inventors who had only primary or secondary education received as many (and often more) patents over their careers as did their peers with more extensive formal schooling. The less-educated inventors also seem to have produced as valuable or technically significant inventions. Their patents were just as likely to be assigned, and just as likely to be cited in applications for patents from later inventors. Thus, the technologically creative seem to have been able to accumulate the skills and knowledge necessary to operate at the frontier largely on their own, or through their work experience as apprentices or younger employees, up until the Second Industrial Revolution. ${ }^{31}$

Some skeptics might suggest that the great inventors who had to make do with little or no formal schooling were not so disadvantaged. That is perhaps the point, at least as regards the sources of technological creativity, but this should not be interpreted as meaning that this class of great inventors was as well off in material terms as those who went to college. Matthias Baldwin, James Eads, George Eastman, Thomas Edison, and Elias Howe are among the many great inventors who were compelled to go to work at an early age to support themselves or their families, and thus to forego much in the way of formal schooling. A perhaps more fundamental question is whether this class of inventors was especially advantaged by the structure of the U.S. patent system, where the cost of obtaining a property right in the new technological knowledge one had discovered was low, the State supported strict enforcement of those rights, and where (between 1790 and 1793, and from 1836 onward) the patent office invested substantial resources in determining the validity of patents before they were granted.

\footnotetext{
${ }^{31}$ The differences in patent systems had implications for how apprenticeship worked, and the effective rights of workers to technological improvements they generated, in Britain and the United States. See Fisk 1998 and MacLeod 1999.
} 
The biographies suggest that inventors with only primary or secondary schooling had more limited financial resources than those who were able to attend college. Given the financial institutions of that era, inventors lacking in wealth would surely have found it much more difficult to extract a return from their inventions, if they had to mobilize the capital to start or conduct a business on their own to exploit their idea directly without patent protection. The lower cost of obtaining a patent, and the certification that stemmed from having successfully passed an examination screening, should have made it much easier for inventors to market the new technology and either extract returns by selling off or licensing the rights to a firm better positioned for commercial exploitation, or to attract investment (by offering shares in a firm whose assets consisted largely of the patent rights to the new technology or commitments by the inventor) to support the continued efforts of the inventor.

Our evidence does indeed suggest that these features of the U.S. patent system were highly beneficial to inventors, and especially to those whose wealth would not have allowed them to directly exploit their inventions through manufacturing or other business activity. The ability to obtain patents provided a means for individuals whose chief asset was technological creativity, or accumulated human capital that was conducive to inventive activity, to extract a return from their talents by focusing on invention. Table 3 shows that a remarkably high proportion of the great inventors, generally near or above half, extracted much of the income from their inventions by selling or licensing off the rights to them. Moreover, it was just those groups that one would expect to be most concerned to trade their intellectual property that were indeed the most actively engaged in marketing their inventions. The great inventors with only a primary school education were most likely to realize the income from their inventions through sale or licensing, whereas those with a college education in a non-technical field were generally among the least likely to 
follow that strategy. ${ }^{32}$ With the exception of the birth cohort of 1739 to 1794 (where there are relatively few observations), the college-educated inventors were much more likely than others to extract the returns to their technological creativity by being a proprietor or principal in a firm that directly exploited the technology in production. ${ }^{33}$ Inventors who chose to realize the fruits of their technological creativity in this way might not seem to have been so affected by the patent system, but in fact even this group benefited. They were obviously helped by holding a monopoly on the use of the respective technology, but many of them were also aided in mobilizing capital for their firms by being able to report patents (or contracts committing patents granted in the future) as assets. Patent portfolios were especially useful as a signal for those who wished to attract venture capital for exceptionally innovative projects that might otherwise have seemed overly risky. ${ }^{34}$

The estimates in Table 3 of the relative prevalence of the approaches used by the great inventors to derive income from their inventions also indicate that the reliance on sales and licensing is quite high among the first birth cohort (51.4 percent on average), and remains high (62.1, 44.0, and 66.0 percent in the next three cohorts), until a marked decline among the last birth cohort, those born between 1866 and 1885. The proportion of great inventors who relied extensively on sales or licensing of patented technologies fell sharply from the levels of preceding cohorts, and there was a rise in the proportion that realized their returns through longterm associations (as either principals or employees) with a firm that directly exploited the

\footnotetext{
${ }^{32}$ Although a bit less striking, the inventors who had studied engineering or a natural science were also, for a time (the middle three birth cohorts), much more inclined to rely on sales or licensing of their inventions to realize income. This pattern might be explained as due to these inventors choosing to specialize in what their human capital gave them a comparative advantage in - inventive activity - and leaving it to others to carry out the commercial exploitation.

${ }^{33}$ Many of the college educated of the 1739-94 birth cohort were evidently not so concerned with realizing a return from their inventions. Fourteen percent of the college educated, and more than one third of those who studied engineering or natural science chose not to pursue returns to their inventions. This attitude, however admirable, was not shared by inventors that came from less privileged backgrounds.
} 
technologies. This finding parallels that of Lamoreaux and Sokoloff (1999a), whose analysis of different data indicated that there was a substantial increase in the likelihood of the most productive inventors forming long-term attachments with a particular assignee over the late-19 and early 20th centuries. ${ }^{35}$

The patterns of variation over educational class and time in the relative prevalence of the different approaches employed by inventors in realizing the returns to their inventive activity, and in the relative productivity or prominence of different sub-groups at invention, are both fascinating and complex. We have highlighted the role of a revolutionary, low-cost, examination-based patent system which, when coupled with favorable legal institutions and strong enforcement, not only encouraged a broad range of creative individuals and firms to invest more in inventive activity, but was especially crucial for those who began without much in the way of resources except for their technological creativity. A key feature of the story, however, is that much of the population possessed some familiarity with the basic elements of technology during this era. Moreover, apprenticeship or the widespread practice of leaving home during adolescence to pick up skills in a trade, a traditional social institution for the transmission and accumulation of more detailed technological knowledge, was both widely accessible and capable of adapting to many of the new developments and to the general quickening of the pace of advance over the $19^{\text {th }}$ century. Technologically creative individuals without the resources to attend institutions of higher learning thus had avenues for acquiring the skills and knowledge necessary to be effective at invention, and could later take advantage of the access to opportunities for inventive activity grounded in the patent system. Good things generally come

\footnotetext{
${ }^{34}$ Lamoreaux, Levenstein, and Sokoloff 2004.

${ }^{35}$ Although deeply impressed with how well this result fits with the work of Lamoreaux and Sokoloff 1999a and 2003, some caution may be warranted. Because the Dictionary of American Biography was originally prepared during the 1920s, our sample does not include as many great inventors born after 1865 as we would like. We would feel a bit more secure with more observations.
} 
to an end, eventually, and in this case circumstances changed over time with the evolution of technology. Formal knowledge of science and engineering became increasingly important for making significant contributions at the technological frontier, particularly with the so-called Second Industrial Revolution, and the cost of carrying out inventive activity rose. Both of these developments served to narrow the range of the population that could generate important inventions, at least to the extent that technologically creative individuals from humble origins found it difficult to gain access to the programs in engineering or natural sciences which proliferated with the expansion of land-grant state universities during the late- $19^{\text {th }}$ century. Given the much higher costs of conducting inventive activity, those who were supplying the capital to fund such endeavors may have reasonably desired more in the way of credentials, as well as long-term commitments, from those they were supporting. This interpretation is obviously somewhat speculative, but does seem to be consistent with the patterns in the data. An alternative perspective is that many of the phenomena we have noted could be explained by changes in the sectoral composition of the economy. In this view, there were always some industries in which formal schooling in a technical field was nearly a prerequisite for significant invention, while in others inventors could make do with little or no formal schooling. The latter industries, such as agriculture or light manufacturing, may have featured prominently in the early industrial economy, and thus created opportunities at invention for the under-schooled, but over time the more capital-intensive and science-based industries grew in importance. The sectoral shifts then led to the dominance among great inventors of those trained in engineering or the natural sciences, as well as to the rise of R \& D laboratories in large integrated companies. Although some aspects of this account ring true, the estimates presented in Table 4 of variation in the educational backgrounds of the great inventors across sectors (and over time) suggest that changes in the sectoral composition of the economy offer little 
explanatory power. Although inventors in the electrical/communications sector (that is, electrical machinery and equipment, telegraph, telephone, radio, etc.) were always slightly more likely to have studied engineering or a natural science, in general the differences across sectors seem very small. Instead, the most striking pattern is that the educational backgrounds of inventors tended to move together over time, with each sector characterized by a marked increase in reliance on inventors educated in engineering or natural sciences during the last two birth cohorts. Although our classification of patents by sector is more aggregated than we would like, the data suggest that the change in the composition of inventors overall was driven more by developments extending across all sectors, rather than by changes in the relative importance of different sectors.

Table 5 presents further evidence of a broad change over time in who was responsible for the most important technological advances, and the growing significance of supporting investments in human and other capital. As seen in the first panel of this table, there was a pronounced shift toward greater specialization at invention (and use of the patent system). The typical great inventor born after 1820 had much longer careers at such activity than those born before, with nearly 60 percent of them receiving patents for more than 30 years (as opposed to roughly 37 percent for the earlier cohort). Moreover, even controlling for the duration of career at invention, the later birth cohort generated many more patents. This tendency toward greater specialization was likely encouraged by the growth of the market for technology (which raised the returns to invention, and also helped inventors who demonstrated creativity at research and development mobilize support) and the increased significance for being productive at invention of having accumulated specialized knowledge and human capital. ${ }^{36}$ Changes in the age of first invention may also reflect these developments. As indicated in the second panel of the table, over time great inventors began producing patented discoveries at somewhat younger ages, and 
on average those who got started earlier ultimately received many more patents over their careers (in total, and per year of career at invention). Accounted for partially by a sharp drop off in the fraction of great inventors who filed their first patent at 35 or older, this distinct pattern seems to suggest that it became more important for the technologically creative to invest in specific human capital or establish a track record early if they were to be productive at invention in later years. It is quite interesting, however, that the great inventors who were older at first patent were proportionally (relative to the number of patents they received) just as likely to receive citations for their achievements; the implication is the late-starters may have generated fewer inventions over their careers, but that the average quality of their discoveries was roughly equivalent to those who began inventing and patenting earlier in life.

\section{INSTITUTIONS, INVENTION AND ECONOMIC DEVELOPMENT}

Invention was a remarkably democratic activity in the United States throughout the $19^{\text {th }}$ century. Although individuals who had been able to study at institutions of higher learning were over-represented among great inventors, those with little in the way of formal schooling were major contributors to the progress of technology. As we have argued before, this era of democratic invention owed much to the broad access to economic opportunities available in an environment where enterprises operated on a small scale, markets were rapidly expanding, and there were relatively modest barriers to entry. In this paper, however, we called attention to a crucial feature of patent institutions whose role has not been fully appreciated. The U.S. patent system was revolutionary in its extension of property rights in technology to an extremely wide spectrum of the population. Moreover, it was exceptional in recognizing that it was in the public interest that patent rights, like other property rights, be clearly defined, well enforced, and easy to

${ }^{36}$ Lamoreaux and Sokoloff 1999a.. 
transact in. These were radical notions in a world accustomed to technology being a free good to all who had the capital to exploit it, except as limited by the authority of the government to arbitrarily grant a monopoly over it. It should be no surprise that they encountered fierce resistance in Old World Europe, at least until the exhibition at Crystal Palace intensified concern with the logic and design of intellectual property institutions. ${ }^{37}$

We have demonstrated the lack of support for the views of those $19^{\text {th }}$ century skeptics who contended that only an elite segment was capable of truly important invention, and therefore that an extension of property rights in technology to the general population would have no beneficial effect and might even retard the pace of technical progress. Although few of the celebrated inventors in Britain were of humble origins, such individuals were well represented among the great inventors of the United States. In the U.S., this group was more likely to invest in inventive activity, not only because of the relatively lower cost of obtaining a patent, but also because the examination system facilitated the use of a patent as a general asset that could be sold, licensed, or offered as collateral for finance. This latter feature was of profound importance for technologically creative individuals who lacked the financial resources to exploit inventions directly. In short, the patent system was a key institution in the progress of technology, but it also stands out as a conduit for creativity and achievement among otherwise disadvantaged groups.

It might be natural to ask whether, if the U.S. system of strong and broadly extended property rights in new technological knowledge was so effective at harvesting the technological creativity of its population, it inspired other nations to adopt such a purportedly successful institutional innovation. As we have suggested, Britain and many other European countries did modify their patent institutions, especially after Crystal Palace, to make them more like the

\footnotetext{
${ }^{37}$ Machlup and Penrose 1950; Penrose 1951; and Rosenberg 1969.
} 
American system. On the whole, however, this institutional convergence might be considered somewhat slow, especially the convergence that was achieved without the influence of the international patent conventions convened over the last few decades of the $19^{\text {th }}$ century (see Table 6). Japan and Germany, for example, stand out as the only leading economies that seem to have enthusiastically (in their initial system designs) joined the U.S. in embracing the examination system (though Russia and the Scandinavian countries also went in that direction, having been much influenced by the German system, with Canada in turn presumably affected by the U.S. practice). How do we make sense of the pattern of institutional diffusion?

Tracing back at least as far as Simon Kuznets and Alexander Gerschenkron, scholars of long-term economic development have wondered whether follower countries naturally evolve, if not benefit from, a systematically different set of institutions than did the early industrializers. Gerschenkron's analysis focused on capital market institutions, but some of his insights might well apply to the question of what sort of patent institutions the follower countries of the $19^{\text {th }}$ century should have adopted. ${ }^{38}$ As with financial capital, follower countries likely had difficulty mobilizing all forms of capital to invest in inventive activity and thus it was perhaps not unreasonable for them to choose to rely on technological knowledge from abroad. Early industrializers, whose populations and industries were more familiar with the frontiers of technology, would not have been so inclined.

It should not be too surprising that those who came after tended to adopt patent systems that were more oriented toward securing flows of technology from outside the country, especially technological knowledge that was embodied in actual plant or production. Except for the U.S, and a few relatively minor exceptions, nearly all societies had working requirements (or in a few

\footnotetext{
${ }^{38}$ Gerschenkron explicitly identified the ability to draw on the technologies developed in those countries that had industrialized earlier as one of the greatest advantages of economic backwardness. See his classic essay, in
} 
cases compulsory licensing) as a central component of their patent systems. Similarly, the great majority of follower countries had provisions for so-called patents of importation -- whereby those who were the first to introduce a new technology to the country (regardless of whether he/she was the inventor) from abroad could obtain a property right (typically lasting until the original foreign patent on the technology expired). ${ }^{39}$ It was only late in the century, after international patent conventions -- under pressure from the United States -- urged countries to adopt the principle that only inventors had the right to a patent, that such awards of property rights to the importer of a technology were disallowed. Even then, many countries specified that the first applicant for a patent would be presumed to be the inventor.

Many argue that extremely underdeveloped countries should have no interest in maintaining a patent system, on the grounds that their citizens would not be very likely to make new contributions to technological knowledge, and thus the only impact would be to increase the flow abroad of licensing fees and other payments for the fruits of technology. This attitude, however, has an uncomfortable resemblance to that early $19^{\text {th }}$ century view that ordinary people could not be expected to produce any truly significant new technical knowledge. We have shown that the latter opinion was incorrect, and though circumstances today are very different, it is far from clear that strong patent systems in developing countries will fail to elicit a supply response

Gerschenkron 1976, chpt. 1.

39 Many of the follower countries assessed very high fees for patents (especially those that are less developed) at rates that are all the more remarkable for the relatively low per capita incomes prevailing there. Indeed, many of the societies in Central and South America are distinguished for having among the highest fees in the world for patent protection, and the pattern holds across quite a range of national institutional heritages (Brazil, British Honduras, and Peru for example). These fees might have been so high because the elites in these extremely unequal societies did not find it in their interest to provide broad access to property rights in new technology. Given that the number of outliers in Central and South America, where inequality in wealth and political influence was extreme, as compared to say Spain and Portugal (which also had rather low per capita incomes), this hypothesis should perhaps not be immediately dismissed. It might be further noted that the influence of colonial heritage is not nearly so powerful as one might have expected. There was, for example, enormous diversity in the characteristics of the patent systems of even the still remaining British colonies. Another rationale is that it provided an effective way of deriving government revenue at the expense of foreigners (who in many of these countries accounted for well over half of all patents). 
in domestic invention. Moreover, one can also justify the implementation of an effective patent system if it were necessary make substantial investments to migrate technologies from abroad or if the cooperation or assistance of the original inventor was an important factor in diffusion. Although Taiwan of the mid-1980s was and is hardly typical of most developing countries, in his careful investigation of the strong patent system suddenly imposed on the country by the U.S., Lo offers persuasive evidence of a powerful response in expenditures on research and development, patenting by Taiwanese residents in the U.S., and foreign direct investment. ${ }^{40}$ More study is needed, but it seems to us premature to dismiss the idea that there could be some formidable benefits to developing countries strengthening their protection of property rights to new technology, especially if such moves involved working requirements.

${ }^{40}$ Lo 2004. 
FIGURE 1

THE RATIO OF ALL ASSIGNMENTS TO PATENTS IN THE U.S., AS COMPARED TO THE RATIO OF ALL ASSIGNMENTS AND LICENSES TO PATENTS

IN BRITAIN, 1870 TO 1900

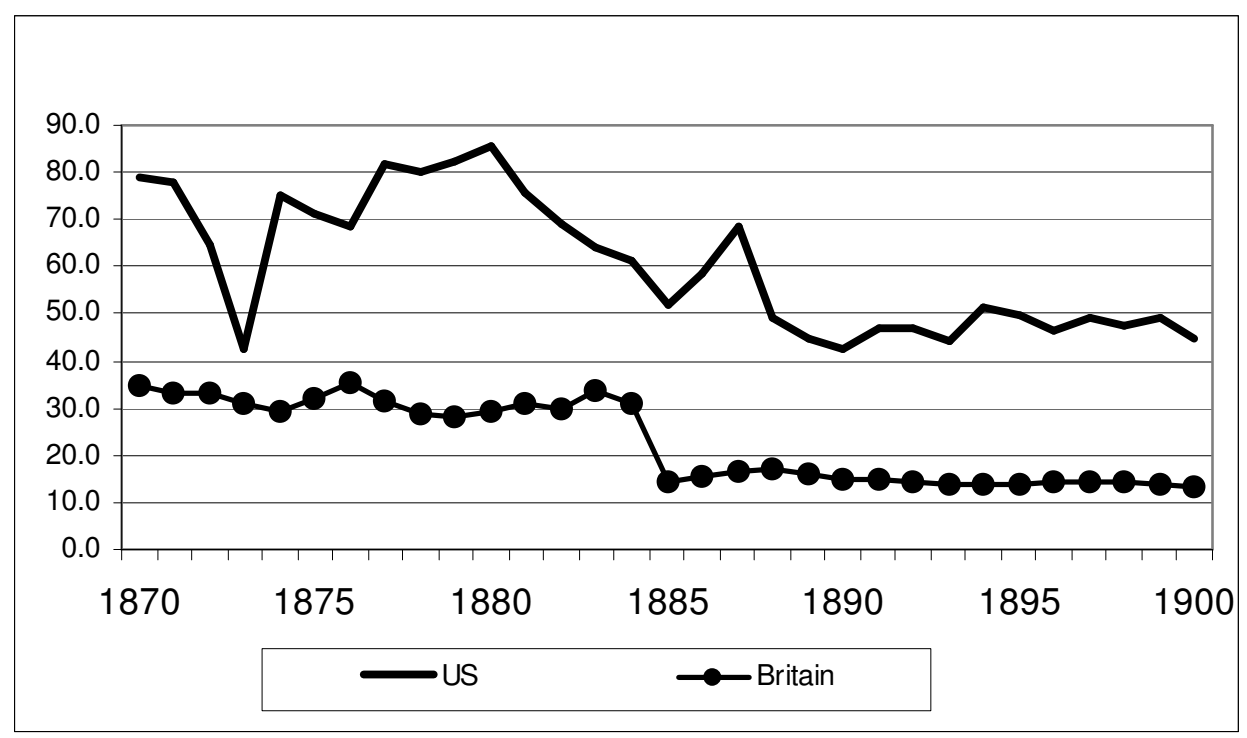

Sources: U.S. Patent Office, Annual Report of the Commissioner of Patents. Washington, D.C.: G.P.O., various years; and Great Britain Patent Office. Annual report of the Commissioners of Patents [after 1883: Annual Report of the Comptroller-General of Patents, Designs and Trade Marks.] London: H.M.S.O., various years. 
TABLE 1

Regional Shares of Total Patents, Great Inventor Patents, and Population, 1790-1930

\begin{tabular}{|c|c|c|c|c|c|c|}
\hline & $\begin{array}{c}1790-1829 \\
(\%)\end{array}$ & $\begin{array}{c}1830-1845 \\
(\%)\end{array}$ & $\begin{array}{c}1846-1865 \\
(\%)\end{array}$ & $\begin{array}{c}1866-1885 \\
(\%)\end{array}$ & $\begin{array}{c}1886-1905 \\
(\%)\end{array}$ & $\begin{array}{c}1906-1930 \\
(\%)\end{array}$ \\
\hline \multicolumn{7}{|l|}{ REGION } \\
\hline \multicolumn{7}{|c|}{ New England } \\
\hline Patents & $34.4 \%$ & $30.1 \%$ & $24.7 \%$ & $19.7 \%$ & $16.7 \%$ & $11.4 \%$ \\
\hline G.I. Patents & 55.1 & 34.1 & 29.6 & 29.1 & 29.1 & 18.3 \\
\hline Population & 21.0 & 13.2 & 10.1 & 9.1 & 7.6 & 7.2 \\
\hline \multicolumn{7}{|c|}{ Middle Atlantic } \\
\hline Patents & 54.5 & 52.3 & 48.3 & 40.6 & 37.6 & 30.8 \\
\hline G.I. Patents & 35.5 & 57.7 & 55.7 & 51.5 & 41.1 & 62.0 \\
\hline Population & 34.4 & 30.0 & 26.5 & 23.1 & 20.5 & 21.1 \\
\hline \multicolumn{7}{|l|}{ Midwest } \\
\hline Patents & 3.0 & 8.3 & 20.8 & 30.3 & 34.5 & 36.8 \\
\hline G.I. Patents & 1.9 & 3.2 & 13.3 & 13.6 & 22.9 & 14.5 \\
\hline Population & 3.3 & 17.3 & 29.2 & 34.0 & 36.0 & 32.6 \\
\hline \multicolumn{7}{|l|}{ South } \\
\hline Patents & 8.1 & 9.2 & 5.1 & 6.0 & 6.8 & 10.8 \\
\hline G.I. Patents & 7.5 & 5.0 & 1.4 & 1.5 & 2.3 & 3.6 \\
\hline Population & 41.3 & 39.7 & 32.9 & 31.9 & 31.5 & 31.7 \\
\hline \multicolumn{7}{|l|}{ West } \\
\hline Patents & -- & -- & 1.0 & 3.4 & 4.6 & 10.2 \\
\hline G.I. Patents & -- & -- & 0.0 & 2.9 & 2.7 & 1.6 \\
\hline Population & -- & -- & 1.4 & 1.9 & 4.5 & 7.5 \\
\hline
\end{tabular}

Notes and Sources: The population figures are from the decadal U.S. Census of Population. The regional distribution of total patents was computed from the Patent Office Annual Reports. The Great Inventor patents for the period before 1865 include all patents filed by great inventors to that date; after 1865 the distribution of great inventor patents refer to a sample of the patents obtained. 
TABLE 2

OTHER DESCRIPTIVE STATISTICS ON GREAT INVENTORS, BY BIRTH COHORT

\section{PRE-1820 BIRTH COHORTS POST-1820 BIRTH COHORTS}

Number $\% \quad$ Number $\%$

Father's Occupation

$\underline{\text { Inventors }}$

$\underline{\text { Inventors }}$

$\begin{array}{lrccc}\text { Artisan } & 17 & 15.6 \% & 36 & 20.3 \% \\ \text { Farmer } & 43 & 39.4 & 37 & 20.9 \\ \text { Eng/Mach/Inventor } & 9 & 8.3 & 25 & 14.1 \\ \text { Professional /Merchant } & 28 & 25.7 & 61 & 34.7 \\ \text { Manufacturer } & 8 & 7.3 & 18 & 10.2 \\ \text { Other } & 4 & 3.7 & -- & --\end{array}$

Career Patents Received, by place of birth of inventor, and proportion of patents received in states other than place of birth

$\underline{\text { Patents }} \underline{\text { Patents }}$

$\begin{array}{lrccc}\text { Northern New England } & 92 & 87.0 \% & 1697 & 97.6 \% \\ \text { Southern New England } & 537 & 55.5 & 1785 & 64.7 \\ \text { New York } & 213 & 34.7 & 1872 & 58.3 \\ \text { Pennsylvania } & 45 & 64.4 & 459 & 67.6 \\ \text { Southern Middle Atlantic } & 118 & 91.5 & 266 & 60.3 \\ \text { South } & 48 & 64.4 & 260 & 87.0 \\ \text { Midwest/West } & 34 & 44.1 & 2670 & 89.6 \\ \text { Foreign Country } & 91 & 100.0 & 3483 & 100.0\end{array}$

Notes and Sources: See text. 
FIGURE 2

THE DISTRIBUTION OF 'GREAT INVENTOR' PATENTS

BY FORMAL SCHOOLING AND BIRTH COHORT

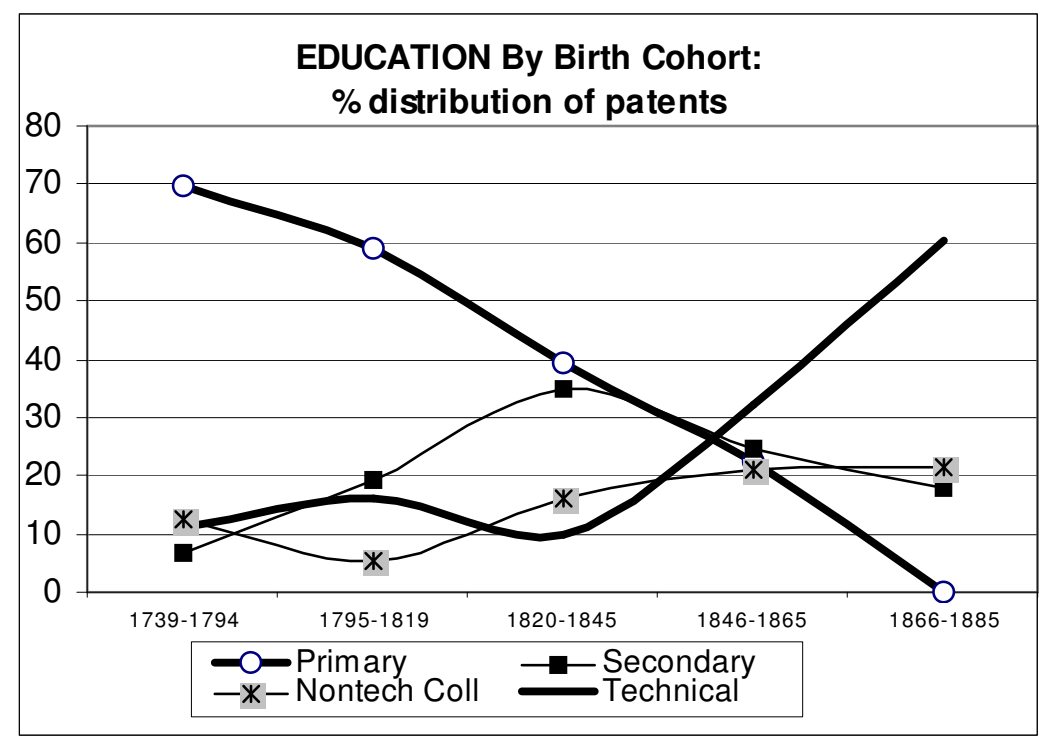

Notes and Sources: See the note to Table 3 and text. 
TABLE 3

DISTRIBUTION OF 'GREAT INVENTOR' PATENTS BY LEVEL OF EDUCATION AND THE MAJOR WAY IN WHICH THE INVENTOR EXTRACTED RETURNS OVER THEIR CAREERS: BY BIRTH COHORTS, 1739-1885

\begin{tabular}{|c|c|c|c|c|c|}
\hline \multirow[b]{2}{*}{ Birth Cohort } & \multirow[b]{2}{*}{ Primary } & \multicolumn{2}{|c|}{ Level of Education } & \multirow[b]{2}{*}{ Eng/NatSci. } & \multirow[b]{2}{*}{ Tot } \\
\hline & & Second. & College & & \\
\hline $1739-1794 \quad$ (row \%) & 69.5 & 6.8 & 12.5 & 11.3 & 400 \\
\hline avg. career patents & 5.6 & 3.8 & 6.5 & 5.2 & 75 \\
\hline sell/license $\quad($ col. \%) & 54.9 & 11.1 & 84.0 & 17.7 & $51.4 \%$ \\
\hline prop/direct $\quad($ col. \%) & 36.5 & 74.1 & 2.0 & 44.7 & $35.6 \%$ \\
\hline employee $\quad($ col. \%) & 6.2 & 7.4 & -- & -- & $4.8 \%$ \\
\hline $1795-1819 \quad($ row $\%)$ & 59.1 & 19.3 & 5.4 & 16.2 & 709 \\
\hline avg. career patents & 20.0 & 14.4 & 17.3 & 12.1 & 80 \\
\hline sell/license (col. \%) & 58.2 & 81.0 & 42.1 & 60.4 & $62.1 \%$ \\
\hline prop/direct (col. \%) & 33.2 & 10.2 & 47.4 & 24.3 & $28.1 \%$ \\
\hline employee (col. \%) & 8.4 & 8.8 & -- & 13.5 & $8.8 \%$ \\
\hline $1820-1845 \quad($ row $\%)$ & 39.2 & 34.7 & 16.3 & 9.7 & 1221 \\
\hline avg. career patents & 41.8 & 44.0 & 29.4 & 23.7 & 145 \\
\hline sell/license (col. \%) & 50.7 & 31.8 & 37.4 & 72.8 & $44.0 \%$ \\
\hline prop/direct (col. \%) & 42.3 & 55.2 & 47.7 & 19.3 & $45.5 \%$ \\
\hline employee (col. \%) & 7.7 & 13.0 & 14.9 & 7.0 & $10.2 \%$ \\
\hline $1846-1865$ (row \%) & 22.2 & 24.5 & 20.9 & 32.4 & 1438 \\
\hline avg. career patents & 158.3 & 73.6 & 78.6 & 55.3 & 80 \\
\hline sell/license (col. \%) & 94.5 & 68.5 & 46.2 & 57.1 & $66.0 \%$ \\
\hline prop/direct (col. \%) & 5.5 & 18.6 & 52.8 & 16.9 & $22.6 \%$ \\
\hline employee (col.\%) & -- & 12.9 & -- & 23.6 & $10.4 \%$ \\
\hline $1866-1885 \quad$ (row \%) & 0.2 & 17.9 & 21.4 & 60.5 & 574 \\
\hline avg. career patents & -- & 144.5 & 53.6 & 155.7 & 26 \\
\hline sell/license (col. \%) & -- & 1.0 & 46.3 & 40.1 & $34.3 \%$ \\
\hline prop/direct (col. \%) & 100.0 & 98.1 & 49.6 & 18.7 & $39.7 \%$ \\
\hline employee (col. \%) & -- & 1.0 & 4.1 & 41.2 & $26.0 \%$ \\
\hline
\end{tabular}


Notes and Sources Table 1: See the text. The table reports: the distribution of great inventor patents across the schooling class of the patentee, by the birth cohort of the inventor; the average number of patents received by each inventor, by birth cohort and schooling class; and the distribution of patents across the principal method of the inventor extracting income, by birth cohort and schooling class. The numbers of patents and great inventors are reported in italics for each birth cohort. The classification of the way income was extracted was arrived at through a close reading of the biographies, and refers to the overall career of the inventor (all of his or her patents). The categories include: inventors who frequently sold or licensed the rights to the technologies they patented; those who sought to directly extract the returns by being a principal in a firm that used the technology in production or produced a patented product; and those who were employees of such a firm. We have omitted a category for those inventors who seem to have made no effort to extract income from their inventions. Our overall sample of 'great inventors' was constructed in two waves. In the first (160 inventors), consisting primarily of those born before 1821 , we collected the information for all of the patents they received through 1865 , and retrieved the information on the number they received after 1865 for our estimates of the total career patents. In the second wave (249 inventors), we collected patents from every fifth year through 1930, and thus will be missing the patents received late in the careers of those of our inventors who were born in the 1870 s and 1880 s. 
TABLE 4

\section{DISTRIBUTION OF ‘GREAT INVENTOR’ PATENTS ACROSS SECTOR}

AND EDUCATION OF INVENTOR: BY BIRTH COHORT, 1739-1885

\begin{tabular}{|c|c|c|c|c|c|c|}
\hline & Agric & Const/CivEng & Elec/Comm & Manuf & Transp & Miscell \\
\hline 1739-1794 & 33 & 27 & 4 & 209 & 99 & 25 \\
\hline Sector share of Patents & $8.3 \%$ & $6.8 \%$ & $1.0 \%$ & $52.6 \%$ & $24.9 \%$ & $6.3 \%$ \\
\hline Primary (col. \%) & 60.6 & 59.3 & -- & 69.4 & 73.7 & 84.0 \\
\hline College (col.\%) & 9.1 & 11.1 & 100.0 & 12.4 & 13.1 & 4.0 \\
\hline Eng/Nat Sci. (col. \%) & 15.2 & 14.8 & -- & 13.4 & 7.1 & 4.0 \\
\hline $1795-1819$ & 61 & 37 & 6 & 316 & 218 & 67 \\
\hline Sector share of Patents & $8.7 \%$ & $5.3 \%$ & $0.9 \%$ & $44.8 \%$ & $30.9 \%$ & $9.5 \%$ \\
\hline Primary (col. \%) & 68.9 & 70.3 & 66.7 & 56.7 & 52.3 & 76.1 \\
\hline College (col.\%) & 21.3 & 5.4 & -- & 5.4 & -- & 9.0 \\
\hline Eng/Nat Sci. (col. \%) & 4.9 & 24.3 & 33.3 & 14.6 & 21.6 & 11.9 \\
\hline $1820-1845$ & 98 & 110 & 73 & 659 & 118 & 144 \\
\hline Sector share of Patents & $8.2 \%$ & $9.2 \%$ & $6.1 \%$ & $54.8 \%$ & $9.8 \%$ & $12.8 \%$ \\
\hline Primary (col. \%) & 24.5 & 41.8 & 11.0 & 44.8 & 49.2 & 27.1 \\
\hline College (col.\%) & 23.5 & 6.4 & 23.3 & 10.8 & 17.8 & 38.2 \\
\hline Eng/Nat Sci. (col. \%) & 2.0 & 20.9 & 17.8 & 9.0 & 7.6 & 6.9 \\
\hline $1846-1865$ & 40 & 154 & 413 & 430 & 261 & 128 \\
\hline Sector share of Patents & $2.8 \%$ & $10.8 \%$ & $29.0 \%$ & $30.2 \%$ & $18.3 \%$ & $9.0 \%$ \\
\hline Primary (col. \%) & 5.0 & 31.2 & 28.8 & 27.9 & 6.5 & 6.3 \\
\hline College (col.\%) & 7.5 & 19.5 & 7.8 & 13.3 & 35.3 & 66.4 \\
\hline Eng/Nat Sci. (col. \%) & 42.5 & 35.1 & 37.5 & 23.0 & 33.3 & 6.3 \\
\hline $1866-1885$ & 7 & 44 & 133 & 213 & 87 & 83 \\
\hline Sector share of Patents & $1.2 \%$ & $7.8 \%$ & $23.5 \%$ & $37.6 \%$ & $15.3 \%$ & $14.6 \%$ \\
\hline Primary (col. \%) & -- & -- & -- & -- & -- & -- \\
\hline College (col.\%) & 28.6 & 6.8 & 49.6 & 23.0 & -- & 2.4 \\
\hline Eng/Nat Sci. (col. \%) & 71.4 & 75.0 & 50.4 & 67.6 & 90.8 & 18.1 \\
\hline
\end{tabular}

Notes and Sources: See the text and the note to Table 1. The distributions of patents across sectors of intended use are reported for each birth cohort of inventors. Within each sector and birth cohort, the table reports the distribution of patents across the educational level of the great inventor. The omitted schooling class is secondary schooling. 
TABLE 5

AGE AND DURATION OF CAREER AT INVENTION, BY BIRTH COHORT

PRE-1820 BIRTH COHORTS

POST-1820 BIRTH COHORTS

Length of Career at Invention (yrs between first and last patent)

\begin{tabular}{lcccccc}
\cline { 2 - 7 } & $\begin{array}{l}\text { \# of } \\
\text { inventors }\end{array}$ & $\%$ & $\begin{array}{l}\text { avg } \\
\text { career pats }\end{array}$ & $\begin{array}{l}\text { \# of } \\
\text { inventors }\end{array}$ & $\%$ & $\begin{array}{l}\text { avg } \\
\text { career pats }\end{array}$ \\
\cline { 2 - 7 } $0-5$ years & 37 & $23.1 \%$ & 1.7 pats & 22 & $8.5 \%$ & 2.2 pats \\
$6-10$ & 8 & 5.0 & 3.5 & 8 & 3.1 & 6.0 \\
$11-20$ & 21 & 13.1 & 6.1 & 36 & 13.8 & 25.9 \\
$21-30$ & 35 & 21.9 & 9.3 & 45 & 17.3 & 30.6 \\
$>30$ years & 59 & 36.9 & 23.9 & 149 & 57.3 & 83.5
\end{tabular}

Age at First Invention

\begin{tabular}{|c|c|c|c|c|c|c|c|c|}
\hline & $\begin{array}{l}\text { \# of } \\
\text { inventors }\end{array}$ & $\%$ & $\begin{array}{l}\text { avg } \\
\text { career pats }\end{array}$ & $\begin{array}{l}\text { avg } \\
\text { citations }\end{array}$ & $\begin{array}{c}\text { \# of } \\
\text { inventors }\end{array}$ & $\%$ & $\begin{array}{l}\text { avg } \\
\text { career pats }\end{array}$ & $\begin{array}{c}\text { avg } \\
\text { citations }\end{array}$ \\
\hline \multicolumn{9}{|c|}{$\begin{array}{l}\text { age at } \\
1^{\text {st }} \text { patent }\end{array}$} \\
\hline$<20$ & 8 & $5.0 \%$ & 9.6 & 1.0 & 3 & $1.2 \%$ & 117.7 & 8.7 \\
\hline $20-24$ & 22 & 13.8 & 19.0 & 0.7 & 35 & 13.7 & 130.6 & 9.9 \\
\hline $25-29$ & 22 & 13.8 & 20.0 & 0.4 & 72 & 27.7 & 64.8 & 4.2 \\
\hline $30-34$ & 35 & 21.9 & 17.8 & 0.5 & 66 & 25.4 & 46.1 & 4.0 \\
\hline $35-39$ & 28 & 17.5 & 7.3 & 0.3 & 33 & 12.7 & 39.0 & 2.5 \\
\hline $40-44$ & 14 & 8.8 & 5.9 & 0.1 & 18 & 6.9 & 28.7 & 2.8 \\
\hline $45-55$ & 21 & 13.1 & 4.6 & 0.0 & 18 & 6.9 & 19.9 & 1.4 \\
\hline
\end{tabular}

Notes and Sources: See Text and footnotes to other tables. 
TABLE 6

SOME DESCRIPTIVE CHARACTERISTICS OF PATENT SYSTEMS

\begin{tabular}{cccc}
\hline $\begin{array}{c}\text { Examination } \\
\text { System }\end{array}$ & $\begin{array}{c}\text { Working Req. } \\
\text { or Compul Lic. }\end{array}$ & $\begin{array}{c}\text { Pats for Import or } \\
\text { Introd. of Technology. }\end{array}$ & Cost \\
\hline
\end{tabular}

Austria

1871

1899

Belgium

1848

1871

1899

Denmark

1871

1899

France

1848

1871

1899

Germany

1891

1899

Great Britain

1848

1871

1899

Italy

1871

1891

1899
$\mathrm{N}$
$\mathrm{N}$
$\mathrm{N}$

$\mathrm{N}$

\section{EUROPE}

Y

$\mathrm{Y}$
Y

$\mathrm{N}$

Y

Y

$\mathrm{N}$

$\overline{\mathrm{N}}$

Y

$-$

$\mathrm{N}$

N

$\mathrm{N}$

Y

Y

$\mathrm{N}$

Y

Y

Y

$\$ \$ \$$ $\$ \$ \$$

$\$ \$$

$\$ \$ \$ \$$

$\$ \$ \$$

$\$ \$ \$$

$\$ \$$

$\$ \$$

$\$ \$$

$\$ \$ \$$

$\$ \$ \$$

$\$ \$ \$$

$\$ \$ \$ \$$

$\$ \$ \$ \$$

$\$ \$ \$ \$$

$\$ \$ \$ \$$

$\$ \$ \$ \$$

$\$ \$$
Norway
1871

1899

Portugal

1848

1899
$\mathrm{N}$

$\mathrm{N}$
Y

$\mathrm{Y}$
$\mathrm{Y}$

Y

Y

Y

$\mathrm{N}$

$\$ \$$

Russia
Y
Prussia

1871

$\mathrm{N}$
$\mathrm{N}$

Y

$\$$

Y \$

$\$ \$$

$\$ \$$

(




\begin{tabular}{cll}
\hline $\begin{array}{c}\text { Examination } \\
\text { System }\end{array}$ & $\begin{array}{l}\text { Working Req. } \\
\text { or Compul Lic. }\end{array}$ & $\begin{array}{l}\text { Pats for Import or } \\
\text { Intro. Of Technology }\end{array}$
\end{tabular}

\begin{tabular}{rlccc}
\hline Spain & & & & \\
1848 & $\mathrm{~N}$ & $\mathrm{Y}$ & $\mathrm{Y}$ & $\$ \$ \$$ \\
1871 & $\mathrm{~N}$ & $\mathrm{Y}$ & $\mathrm{Y}$ & $\$ \$ \$$ \\
1899 & $\mathrm{~N}$ & $\mathrm{Y}$ & $\mathrm{Y}$ & $\$ \$$
\end{tabular}

Sweden

1848

1871

1899
--
--
$\mathrm{Y}$
$\mathrm{Y}$
$\mathrm{Y}$
$\$ \$$

$\$ \$$

\section{SOUTH AND CENTRAL AMERICA}

Argentina

1891

Brazil

1871

1891

1899
N

$\mathrm{N}$
$\mathrm{N}$
$\mathrm{N}$

Br. Guiana

1891

N

N

Y
Y
Y

Y

$--$

$\mathrm{N}$

Y

$\$ \$ \$ \$$

$\$ \$ \$$

$\$ \$ \$ \$$

$\$ \$ \$ \$$

$\$ \$ \$ \$$

Br. Honduras

1891

$\mathrm{N}$

$\mathrm{N}$

$-$

$\$ \$ \$ \$$

Chile

$$
1891
$$

$\mathrm{N}$

Y

$-$

$\$ \$ \$$

Colombia

1891

$\mathrm{N}$

Y

$-$

$\$ \$ \$$

Cuba

1871

$\mathrm{N}$

Y

Y

$\$ \$ \$$

Ecuador

$$
1891
$$

N

Y

Y

$\$ \$$

Guatemala

1891

$\mathrm{N}$

Y

Y

$\$ \$ \$$

Mexico

1899

$\mathrm{N}$

$\mathrm{N}$

Y

$\mathrm{N}$

N

$\mathrm{N}$

$\$ \$ \$ \$$

$\$ \$ \$ \$$

Peru 1891

$\mathrm{N}$

Y

N

$\$ \$ \$ \$$ 


\begin{tabular}{|c|c|c|c|c|}
\hline & $\begin{array}{l}\text { Examination } \\
\text { System }\end{array}$ & $\begin{array}{l}\text { Working Req. } \\
\text { or Compul Lic. }\end{array}$ & $\begin{array}{l}\text { Pats for Import or } \\
\text { Intro of Technology }\end{array}$ & Cost \\
\hline \multicolumn{5}{|l|}{ Uruguay } \\
\hline 1891 & $\mathrm{~N}$ & $\mathrm{Y}$ & - & $\$ \$ \$ \$$ \\
\hline \multicolumn{5}{|l|}{ Venezuela } \\
\hline 1891 & $\mathrm{~N}$ & $\mathrm{Y}$ & $\mathrm{N}$ & $\$ \$ \$ \$$ \\
\hline \multicolumn{5}{|c|}{ OTHERS } \\
\hline \multicolumn{5}{|l|}{ Barbados } \\
\hline 1891 & $\mathrm{~N}$ & Y & - & $\$ \$ \$$ \\
\hline \multicolumn{5}{|l|}{ Canada } \\
\hline 1871 & -- & $\mathrm{Y}$ & $\mathrm{N}$ & $\$$ \\
\hline 1899 & $\mathrm{Y}$ & $\mathrm{Y}$ & $\mathrm{N}$ & $\$$ \\
\hline \multicolumn{5}{|l|}{ Fiji } \\
\hline 1891 & $\mathrm{~N}$ & $\mathrm{~N}$ & - & $\$ \$$ \\
\hline \multicolumn{5}{|l|}{ Hawaii } \\
\hline 1891 & $\mathrm{Y}^{*}$ & $\mathrm{~N}$ & $\mathrm{Y}$ & $\$ \$$ \\
\hline \multicolumn{5}{|l|}{ India } \\
\hline 1891 & $\mathrm{~N}$ & $\mathrm{Y}$ & - & $\$ \$ \$ \$$ \\
\hline \multicolumn{5}{|l|}{ Jamaica } \\
\hline 1891 & $\mathrm{~N}$ & $\mathrm{Y}$ & - & $\$ \$ \$$ \\
\hline \multicolumn{5}{|l|}{ Japan } \\
\hline 1899 & $\mathrm{Y}$ & $\mathrm{Y}$ & $\mathrm{N}$ & $\$ \$$ \\
\hline \multicolumn{5}{|l|}{ Liberia } \\
\hline 1891 & $\mathrm{Y}^{*}$ & $\mathrm{Y}$ & - & $\$ \$ \$$ \\
\hline \multicolumn{5}{|c|}{ New South Wales } \\
\hline 1891 & $\mathrm{~N}$ & $\mathrm{~N}$ & $\mathrm{~N}$ & $\$$ \\
\hline \multicolumn{5}{|l|}{ New Zealand } \\
\hline 1891 & $\mathrm{~N}$ & $\mathrm{Y}$ & $\mathrm{N}$ & $\$ \$$ \\
\hline \multicolumn{5}{|l|}{ South Africa } \\
\hline 1891 & $\mathrm{~N}$ & $\mathrm{~N}$ & -- & $\$ \$ \$$ \\
\hline \multicolumn{5}{|l|}{ United States } \\
\hline 1848 & $\mathrm{Y}$ & $\mathrm{N}$ & $\mathrm{N}$ & $\$$ \\
\hline 1899 & Y & $\mathrm{N}$ & $\mathrm{N}$ & $\$$ \\
\hline
\end{tabular}


Notes and Sources:

* Although this country officially had an examination system, its patent office does not appear to have carried out a serious examination of applications for novelty or utility.

1848: John Kingsley and Joseph Piesson, Laws and Practice of All Nations and Governments Relating to Patents of Inventions (New York: Kingsley and Piesson, 1848).

1871: United States and International Patent Office Manual (New York: Fitch and Co., 1871).

1891: Epitome of the World's Patent Laws and Statistics (New York: The British and European Patent Agency, 1891).

1899: Arthur Greeley, Foreign Patent and Trademark Laws (Washington, D.C.: John Byrne and Co., 1899). 


\section{BIBLIOGRAPHY}

British Parliamentary Papers. 1968. Reports from Select Committees on the Law Relative to Patents for Inventions, 1829-72. 2 vols. Shannon: Irish University Press.

Bugbee, Bruce Willis. 1967. Genesis of American patent and copyright law. Washington: Public Affairs Press.

Coulter, Moureen. 1991. Property in Ideas: the Patent Question in Mid-Victorian England. Kirksville, MO: Thomas Jefferson Press.

Cubberley Ellwood P. 1920. The History of Education. Boston: Houghton Mifflin. 1947. Public Education in the United States, A Study and Interpretation of American Educational History. Boston: Houghton Mifflin.

Dictionary of American Biography. 1928-36. New York: C. Scribner's.

Dutton, Harold I. 1984. The Patent System and Inventive Activity during the Industrial Revolution, 1750-1852. Manchester, UK: Manchester University Press.

Fessenden, Thomas G. 1810. An Essay on the Law of Patents for New Inventions. Boston: Mallory \& Co.

Fisk, Catherine L. 1998. "Removing the 'Fuel of Interest' from the 'Fire of Genius': Law and the Employee-Inventor, 1830-1930.” University of Chicago Law Review 65 (Fall): 1127-1198.

Gerschenkron, Alexander. 1976. Economic Backwardness in Historical Perspective. Cambridge: Belknap Press.

Hilaire-Pérez, Liliane. 1994. Inventions et Inventeurs en France et en Angleterre au XVIIIè siècle. Lille: Université de Lille. 2000. L'invention technique au siècle des Lumières. Paris : Albin Michel.

Johnson, James and J. Henry Johnson. 1890. The Patentee's Manual: A Treatise on the Law and Practice of Patents for Invention. London: Longmans, Green \& Co.

Khan, B. Zorina. 1995. "Property Rights and Patent Litigation in Early Nineteenth-Century America," Journal of Economic History 55 (March): 58-97. 2004 (forthcoming). The Democratization of Invention: Patents and Copyrights in American Economic Development, 1790-1920. New York: Cambridge University Press.

Khan, B. Zorina and Kenneth L. Sokoloff. 1993. "Schemes of Practical Utility." Journal of Economic History 53 (June): 289-307.

1998. "Two Paths to Industrial Development and Technological Change," in Maxine Berg and Kristine Bruland, eds., Technological Revolutions in Europe, 1760-1860. Cheltenham: Edward Elgar: 292-313. 
. 2001. "The Early Development of Intellectual Property Institutions in the United States," Journal of Economic Perspectives, vol. 15 (3): 233-246.

. 2004. "Institutions and Democratic Invention in $19^{\text {th }}$ Century America," American Economic Review, vol. 94 (May).

Lamoreaux, Naomi R., Maragret A. Levenstein, and Kenneth L. Sokoloff. 2004. "Financing Invention During the Second Industrial Revolution: Cleveland, Ohio, 1870-1920." unpublished working paper.

Lamoreaux, Naomi R. and Kenneth L. Sokoloff. 1996. "Long-Term Change in the Organization of Inventive Activity," Proceedings of the National Academy of Sciences 93 (Nov): 12686-92.

. 1999a. "Inventors, Firms, and the Market for Technology in the Late Nineteenth and Early Twentieth Centuries," in Naomi R. Lamoreaux, Daniel M.G. Raff, and Peter Temin, eds., Learning By Doing in Markets, Firms, and Countries. Chicago: University of Chicago Press.

. 1999b. "The Geography of the Market for Technology in the Late-Nineteenth and Early-Twentieth Century United States," in Gary D. Libecap, ed., Advances in the Study of Entrepreneurship, Innovation, and Economic Growth. Stamford, CT: JAI Press.

. 2003. "The Decline of the Independent Inventor: A Schumpeterian Story?" unpublished working paper.

Lo Shih-Tse. 2004. "Strengthening Intellectual Property Rights: The Experience of the 1986 Taiwanese Patent Reforms." University of California, Los Angeles: unpublished doctoral dissertation.

Machlup, Fritz and Edith Penrose. 1950. "The Patent Controversy in the Nineteenth Century." Journal of Economic History 10 (March): 1-29.

MacLeod, Christine. 1988. Inventing the Industrial Revolution. Cambridge: Cambridge University Press.

1999. "Negotiating the Rewards Of Invention: The Shop-Floor Inventor in Victorian Britain.” Business History 41 (2): 17-36.

Marcellin, Yves. 1983. La Procédure Française de Délivrance des Brevets d'Invention. RosnySous-Bois: Editions Cédat.

McCloy, Shelby T. 1952. French Inventions of the Eighteenth Century. Lexington: University of Kentucky Press.

Perpigna, Antoine. 1834 and 1852. The French law and practice of patents for inventions, improvements, and importations. Philadelphia: J. S. Littell.

Perpigna, Antoine. 1852. Manuel des inventeurs et des brevetés, 8. éd. Paris: Chez l'auteur.

Penrose, Edith Tilton. 1951. The Economics of the International Patent System. Baltimore: Johns 
Hopkins Press.

Pouillet, Eugene. 1879. Traité Théorique et Pratique des Brevets d'Invention. Paris: Marchal et Billard.

Redondi, Pietro. 1988. "Nation et entreprise: la Société d'Encouragement pour l'Industrie Nationale, 1801-1815," in P. Redondi and R. Fox (eds.) - History and Technology vol. 5 (2-4) Special Issue, French Institutions from the Revolution to the Restoration.

Rosenberg, Nathan, ed. 1969. The American System of Manufactures: The Report of the Committee on the Machinery of the United States 1855, and the Special Reports of George Wallis and Joseph Whitworth 1854. Edinburgh: Edinburgh University Press.

Snyder, Thomas D. 1993. 120 Years of American Education: A Statistical Portrait. Washington, D.C.: U.S. Department of Education, National Center for Education Statistics.

Sokoloff, Kenneth L. 1988. "Inventive Activity in Early Industrial America: Evidence from Patent Records, 1790-1846." Journal of Economic History 48 (Dec.): 813-50.

Sokoloff, Kenneth L. and B. Zorina Khan. 1990. "The Democratization of Invention in During Early Industrialization: Evidence from the United States, 1790-1846." Journal of Economic History 50 (June): 363-78.

Vojacek, Jan. 1936. A Survey of the Principal National Patent Systems. New York: Prentice-Hall. 